UDK 581.19:547.56]:582.971.1

\title{
TOTAL PHENOLICS, ANTIOXIDATIVE AND ANTIMICROBIAL ACTIVITY OF METHANOL EXTRACTS OF BERRIES OF SYMPHORICARPOS ALBUS (L.) S.F.BLAKE, $S$. $\times$ CHENAULTII REHDER AND $S$. ORBICULATUS MOENCH
}

Ukupni fenoli, antioksidativna i antimikrobna aktivnost metanolnih ekstrakata bobica Symphoricarpos albus (L.) S.F.Blake, S. $\times$ chenaultii Rehder i S. orbiculatus Moench Fatima Pustahija ${ }^{1}$, Mirel Subašić ${ }^{1}$, Mirnesa Mulić ${ }^{2}$, Neđad Bašić ${ }^{1}$

\begin{abstract}
Methanol extracts obtained from the berries of three Symphoricarpos taxa (Caprifoliaceae) were used to determine their total phenols concentrations, and antioxidant and antimicrobial activities. According to our knowledge, total concentrations of phenolic compounds and antimicrobial activities for of $S$. $\times$ chenaultii and $S$. orbiculatus, as well as antioxidant activity of all three analyzed taxa are for the first time analyzed in this study. Based on obtained results, it was noticed that the highest average values of the total phenols, flavonoids and flavanols had methanol extracts of $S$. orbiculatus berries $\left(3.525 \mathrm{mg} \mathrm{GAE} \mathrm{g}^{-1} \mathrm{DW}\right.$, and 11.037 and $0.881 \mathrm{mg} \mathrm{CE} \mathrm{g}^{-1} \mathrm{DW}$, respectively), while methanol extracts of $S$. albus berries had the lowest (1.430 mg GAE g $\mathrm{g}^{-1} \mathrm{DW}$, and 4.154 and $0.211 \mathrm{mg} \mathrm{CE} \mathrm{g}^{-1} \mathrm{DW}$ respectively). Symphoricarpos orbiculatus extract $\left(\mathrm{IC}_{50}=5.299 \mathrm{mg} \mathrm{mL}^{-1}\right)$ possessed the highest antioxidant activity while the lowest had $S$. albus $\left(\mathrm{IC}_{50}=20.017 \mathrm{mg} \mathrm{mL}^{-1}\right)$. The methanol extracts of analyzed Symphoricarpos taxa showed no antifungal activity against $C$. albicans. Moderate antibacterial activity of $S$. albus methanol extract is determined against five tested bacterial strains (Bacillus vulgatus, Enterococcus faecalis, Pseudomonas aeruginosa, Salmonella abony, and Staphylococcus aureus), and $S . \times$ chenaultii extract showed a low antibacterial activity only against $P$. aeruginosa, B. vulgatus and $S$. aureus. Although $S$. orbiculatus methanolic extract had the highest antioxidant activity it did not show any antibacterial activity at all. Analyzed Symphoricarpos extracts are potentially effective and can be used as natural antioxidant and antimicrobial preparations against test microorganisms.
\end{abstract}

Key words: antibacterial, antifungal, Caprifoliaceae, phenolic compounds, snowberry

\section{INTRODUCTION - Uvod}

Plants are able to synthesize variety of secondary metabolites with antioxidant and antimicrobial properties, whereby phenolics and phenolic-related compounds take up a very important place in medicine, pharmacology, food processing and cosmetics

\footnotetext{
${ }^{1}$ Faculty of Forestry, University of Sarajevo, Bosnia and Herzegovina

${ }^{2}$ Public Forestry Enterprise ZE-DO Canton Zavidovići doo, Business unit „Forestry Zenica“, 72000 Zenica, Bosnia and Herzegovina
} 
industry (CROZIER et al., 2006; VERMERRIS and NICHOLSON, 2008). Accordingly, identification, valorisation and using of plant extracts with different bioactive properties are very intriguing objects for further researches.

Genus Symphoricarpos (Caprifoliaceae; snowberry, waxberry, or ghostberry) comprises about 15 species of deciduous shrubs, native to Central and North America except one species in parts of China. Snowberries are ornamental shrubs, grown for their decorative berries and tremendous versatility (EVERETT, 1982; JACOBS et al., 2009).

All three analyzed taxa in this study [Symphoricarpos albus (L.) S.F.Blake (common snowberry), $S$. × chenaultii Rehder (Chenault coralberry; hybrid of $S$. microphyllus $\times S$. orbiculatus) and S. orbiculatus Moench (coralberry, buckbrush or Indian currant)] are important food source for birds during winter seasone, used for erosion control and in ecological restoration projects on disturbed sites, and valuable ornamental plants (JONES, 1940; HESSAYON, 1994; VUKIĆEVIĆ, 1996).

Although different parts of snowberries are used in traditional medicine in some countries, the phytochemical composition of the Symphoricarpos species is not sufficiently analyzed except for the $S$. albus (SZAUFER-HAJDRYCH and ZGÓRKA, 2003 and literature cited therein; SZAUFER-HAJDRYCH and GOŚLIŃSKA, 2004; MALYI and KHVOROST, 2013). Symphoricarpos albus and S. occidentalis possess flavonoids and their glycosides, organic acids, oxidative phenols, hydroxycinnamic acids, coumarins, tannins, carbohydrates, pectins, iridoids, saponins, triterpenes, isoquinoline alkaloids and cholines (WILLUHN et al., 1983; HALLARD et al., 1998; SZAUFER-HAJDRYCH and ZGÓRKA, 2003; KIM et al., 2004; SZAUFER-HAJDRYCH and GOŚLIŃSKA, 2004; KOVALENKO et al., 2007; MAKAREVICH et al., 2009; MALYI and KHVOROST, 2013).

It has been shown that various snowberries parts have diuretic, emetic, laxative, anti-inflammatory, and antimicrobial activity and are used to treat dermatological disorders (NICKELL, 1959; SEIGLER, 1998; MOERMAN, 1998; SZAUFER-HAJDRYCH and ZGÓRKA, 2003; SZAUFER-HAJDRICH and GOŚLIŃSKA, 2004; LANS et al., 2007; JURIKOVA et al., 2012), as well as that $S$. albus branches are used to eliminate endoparasites (LANS et al., 2007).

The aims of this study were to determine total content of phenols, flavonoids and flavanols, and to evaluate antioxidant and antimicrobial activity of methanol extracts of berries of Symphoricarpos albus, $S . \times$ chenaultii and S. occidentalis.

\section{MATERIAL AND METHODS - Materijal i metode}

\section{Plant material - Biljni materijal}

Berries of three individuals of all analyzed Symphoricarpos taxa were collected in two Sarajevo's parks (the Great Park and park near Historical Museum of Bosnia and Herzegovina) during November of 2015. In the laboratory, berries were washed with running tap water, rinsed with distilled water and dried during 48 hours at $50-60^{\circ} \mathrm{C}$. Dried materials were grounded into powder by liquid nitrogen and stored 
in glass bottles $\left(4^{\circ} \mathrm{C}\right)$ until extraction processes. Voucher specimens have been deposited in the herbarium of the Faculty of Forestry, University of Sarajevo.

\section{Chemicals and reagents - Hemikalije i reagensi}

Gallic acid, catechin and DPPH are HPLC purity, and other used chemicals and solvents were of analytical grade purchased from Sigma-Aldrich (Steinheim, Germany).

\section{Methanol extracts preparation - Pripremanje metanolnih ekstrakata}

Powdered dry berries $(0.08 \mathrm{~g})$ were extracted with $80 \%$ aqueous methanol $(2 \mathrm{x}$ $4 \mathrm{~mL}$ ) in an ultrasonic bath (Elmasonic $\mathrm{S} 60 \mathrm{H}$ ) for 30 minutes. Extracts were then centrifuged at 2,000 rpm for 15 minutes (Centric $322 \mathrm{~B}$, Techtnica). Obtained supernatants were combined, filtrated and volume of the extract was adjusted with extraction mixture up to $8 \mathrm{~mL}$, and evaporated to dryness. Such obtained residues were stored at $4^{\circ} \mathrm{C}$ until further use. The solid residues were resuspended in $80 \%$ aqueous methanol to obtained $10 \mathrm{mg} \mathrm{mL}^{-1}$ concentration. For determination of phenolic contents and antioxidant activity of all methanol extracts is used Shimadzu UV-mini 1240 spectrophotometer. All values are presented as means of triplicate analyses.

\section{Determination of total phenols - Odredivanje ukupnih fenola}

The amount of total phenolic content in extracts was determined according to the modified Folin-Ciocalteu procedure (WOLFE et al., 2003). Diluted methanol sample $(20 \mu \mathrm{L})$ was mixed with $100 \mu \mathrm{L}$ of Folin-Ciocalteu's reagent and $300 \mu \mathrm{L}$ of freshly prepared sodium carbonate solution (7.5\%). After homogenisation, the samples were incubated for 30 minutes at $45^{\circ} \mathrm{C}$ in water bath. The absorbance of the coloured solvents was measured at $765 \mathrm{~nm}$ against the blank and calibration curve was prepared with gallic acid as a standard. Total phenolic content was expressed as $\mathrm{mg}$ of gallic acid equivalents per gram of dry plant sample $\left(\mathrm{mg} \mathrm{GAE}^{-1}\right)$.

\section{Determination of total flavonoids - Određivanje ukupnih flavonoida}

Determination of total flavonoid content was done using modified method of ORDOÑEZ et al. (2006). Diluted methanol extract aliquots $(20 \mu \mathrm{L})$ were mixed with $105 \mu \mathrm{L}$ of distilled water, $25 \mu \mathrm{L}$ of $10 \%$ aluminium chloride water solution and $25 \mu \mathrm{L}$ of $1 \mathrm{M}$ sodium acetate water solution, followed by the addition of $700 \mu \mathrm{L}$ of distilled water and $375 \mu \mathrm{L} 96 \%$ of methanol. After homogenization, the mixtures were incubated at room temperature for 20 minutes. The absorbance of coloured samples was measured at $415 \mathrm{~nm}$ against the blank. Total flavonoid content was expressed as $\mathrm{mg}$ of catechin equivalent per gram of dry sample $\left(\mathrm{mg} \mathrm{CE} \mathrm{g}^{-1}\right)$.

\section{Determination of total flavanols - Odredivanje ukupnih flavanola}

Determination of total flavanols was carried out using modified GADZOVSKA et al. (2007) method. Analysed methanol samples $(200 \mu \mathrm{L})$ are mixed with $1000 \mu \mathrm{L}$ of 
0.1\% DMACA reagent (p-(Dimethylamino)cinnamaldehyde) and mixtures were incubated for 10 minutes at room temperature. Absorbance was measured at $640 \mathrm{~nm}$ against the blank. The results were expressed as catechin equivalents per gram of dry sample ( $\left.\mathrm{mg} \mathrm{CE} \mathrm{g}^{-1}\right)$.

\section{Determination of antioxidant activity by DPPH method - Odredivanje antioksidativne aktivnosti DPPH metodom}

The total antioxidant activity of methanol extracts of berries was measured by DPPH free radical scavenging modified method by MEDA et al. (2005). Aliquots of diluted methanol extracts were mixed with freshly prepared ethanol DPPH solution and incubated for 30 minutes at room temperature in the dark. The absorbance of the solutions was measured at $517 \mathrm{~nm}$ against $96 \%$ ethanol as a blank.

The DPPH scavenging effect was calculated as follows: DPPH scavenging effect $(\%)=\left[\left(A_{a}-A_{b}\right) / A_{a}\right] \times 100$; in which $A_{a}$ is the absorbance of DPPH blank, and $\mathrm{A}_{\mathrm{b}}$ is the absorbance of DPPH with sample in different concentrations. The antioxidant activity was expressed as half maximal inhibition concentration $\left(\mathrm{IC}_{50}\right)$, calculated graphically based on the calibration curves for each sample. The lower $\mathrm{IC}_{50}$ values indicated the higher antioxidant activity in the methanol extracts.

\section{Estimation of antimicrobial activity - Procjena antimikrobne aktivnosti}

Antimicrobial activity of analyzed methanol extracts against gram positive (Bacillus vulgatus $\mathrm{ATCC}^{\circledR} 8482^{\mathrm{TM}}$, Enterococcus faecalis $\mathrm{ATCC}^{\circledR} 19433^{\mathrm{TM}}$ and Staphylococcus aureus $\mathrm{ATCC}^{\circledR} 6538^{\mathrm{TM}}$ ) and gram negative (Pseudomonas aeruginosa ATCC $^{\circledR} 9027^{\mathrm{TM}}$ and Salmonella abony $\mathrm{NCTC}^{\circledR} 6017^{\mathrm{TM}}$ ) bacteria and one fungus Candida albicans ATCC $^{\circledR} 10231^{\mathrm{TM}}$ was done by standard disc diffusion method (BAUER et al., 1966).

Sterile Müeller Hinton and Sabouraud dextrose agars in Petri dishes were inoculated with $1 \mathrm{~mL}$ of bacterial and fungal suspension, respectively. Afterward, on the inoculated agars are placed sterile discs, $6 \mathrm{~mm}$ in diameter (Whatman Antibiotic Assay Discs), impregnated with $25 \mu \mathrm{L}$ of methanol extracts. Disc with $80 \%$ methanol was used as blank control, and standard discs of Amoxicillin (Amx10mcg, HiMedia) and Nystatin $(10.000 \mathrm{U} / \mathrm{mL}$, Semikem) served as positive antibiotic controls. The treated plates were incubated at $37^{\circ} \mathrm{C}$ for 24 hours after which antimicrobial activity was assessed by measuring the zone of growth inhibition around the discs.

\section{Statistical analysis - Statistička analiza}

Obtained data were performed with the SPSS statistical software program (IBM SPSS statistics 20, USA). Means were expressed with their standard errors and compared by one-way analysis of variance (ANOVA). To determine the significant differences between groups, after analysis of variance, Duncan's post-hoc test was used at $\mathrm{p}<0.05$. 


\section{RESULTS AND DISCUSSION - Rezultati i diskusija}

In methanol extracts of berries of analyzed Symphoricarpos taxa, the UV/VIS spectrophotometric method confirmed the presence of phenols, flavonoids, flavanols and antioxidant activity (Table 1). Methanol extracts of $S$. orbiculatus have had the highest mean values of total phenols, flavonoids and flavanols (3.525 $\mathrm{mg} \mathrm{GAE} \mathrm{g}^{-1}$ DW, 11.037 and $0.881 \mathrm{mg} \mathrm{CE} \mathrm{g}^{-1} \mathrm{DW}$, respectively), and S. albus the lowest (1.430

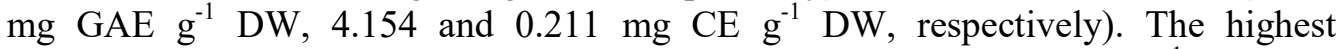
antioxidant activity was observed in $S$. orbiculatus $\left(\mathrm{IC}_{50}=5.299 \mathrm{mg} \mathrm{mL}^{-1}\right)$, and the lowest in S. albus $\left(\mathrm{IC}_{50}=20.017 \mathrm{mg} \mathrm{mL}^{-1}\right)$.

Table 1. Basic descriptive parameters of phenolic compunds for analyzed Symphoricarpos berries $\left[\mathrm{mg} \mathrm{g}^{-1}\right.$ of dry weight; $\mathrm{X} \pm \mathrm{SD}(\% \mathrm{CV}) ; \mathrm{X}$ - average, SD - standard deviation, $\mathrm{CV}$ coefficient of variation, $\mathrm{IC}_{50}$ - antioxidative activity $\left.\left(\mathrm{mg} \mathrm{mL}^{-1}\right)\right]$.

Tabela 1. Osnovni deskriptivni parametri fenolnih jedinjenja za istraživane bobice biseraka [mg $\mathrm{g}^{-1}$ suhe materije; $X \pm S D(\% C V)$; X-srednja vrijednost, $S D$ - standardna devijacija, $C V$ koeficijent varijacije, $I C_{50}$ - antioksidativna aktivnost $\left.\left(m g L^{-1}\right)\right]$.

\begin{tabular}{lcccc}
\hline $\begin{array}{c}\text { Parameter/ } \\
\text { Taxon }\end{array}$ & Phenols $^{\mathbf{a}}$ & Flavonoids $^{\mathbf{b}}$ & Flavanols $^{\mathbf{b}}$ & IC $_{\mathbf{5 0}}$ \\
\hline S. albus & $1.430 \pm 0.256$ & $4.154 \pm 0.525$ & $0.211 \pm 0.052$ & $20.017 \pm 1.803$ \\
& $(17.909)$ & $(12.636)$ & $(24.472)$ & $(9.006)$ \\
S. $\times$ chenaultii & $2.374 \pm 0.176$ & $5.372 \pm 0.665$ & $0.388 \pm 0.197$ & $6.976 \pm 1.050$ \\
& $(7.406)$ & $(12.374)$ & $(50.698)$ & $(15.052)$ \\
S. orbiculatus & $3.525 \pm 0.156$ & $11.037 \pm 0.591$ & $0.881 \pm 0.222$ & $5.299 \pm 0.476$ \\
& $(4.430)$ & $(5.357)$ & $(25.222)$ & $(8.977)$ \\
\hline
\end{tabular}

Note: $\mathrm{a}$ - expressed as $\mathrm{mg} \mathrm{g}^{-1} \mathrm{GA}$ (gallic acid), $\mathrm{b}$ - expressed as $\mathrm{mg} \mathrm{g}^{-1} \mathrm{C}$ (catechin)

The presence of significant differences in concentrations of total phenols, flavonoids and flavanols, and antioxidative activity between snowberries analyzed $(\mathrm{p}<0.05)$ was confirmed by $t$-test. Also, the $t$-test confirmed that there were no statistically significant differences between the antioxidant activity of methanol samples of $S$. × chenaultii and $S$. orbiculatus.

Table 2 shows the antimicrobial activity of methanol extracts of berries of the Symphoricarpos taxa analyzed. Methanol extracts of $S$. albus berries showed low to moderate antibacterial activity against test microorganisms but not antifungal activity against $C$. albicans. Reduced antimicrobial activity showed methanol extracts of $S$. $\times$ chenaultii against gram-negative Pseudomonas aeruginosa and gram-positive bacteria Bacillus vulgatus and Staphylococcus aureus. No antimicrobial activity against six treated microorganisms was observed after methanol extracts treatments of $S$. orbiculatus. 
Table 2. Antimicrobial activity (expressed as zone of inhibition) of methanol extracts of berries of analyzed Symphoricarpos taxa against selected microbial strains (mean \pm S.D., $\mathrm{n}=3$ )

Tabela 2. Antimikrobna aktivnost (izražena kao zona inhibicije) metanolnih ekstrakata bobica analiziranih vrsta Symphoricarpos protiv odabranih mikrobnih sojeva (srednja vrijednost \pm S.D., $n=3$ )

\begin{tabular}{lcccccc}
\hline \multirow{2}{*}{ Extract } & \multicolumn{6}{c}{ The diameter of the inhibition zone (mm) } \\
\cline { 2 - 7 } & CA & BV & EF & PA & SA & SAu \\
\hline S. albus & $/$ & $9.15 \pm 0.17$ & $8.85 \pm 0.14$ & $10.26 \pm 0.1$ & $9.36 \pm 0.12$ & $11.61 \pm 0.1$ \\
S. $\times$ chenaultii & $/$ & $7.59 \pm 0.14$ & $/$ & $8.21 \pm 0.15$ & $/$ & 6 \\
S. orbiculatus & $/$ & $/$ & $/$ & $/$ & $/$ & 8 \\
\hline
\end{tabular}

Note: CA - Candida albicans, BV - Bacillus vulgatus, EF - Enterococcus faecalis, PA Pseudomonas aeruginosa, SA - Salmonella aboni, SAu - Staphylococcus aureus.

\section{DISCUSSION - Diskusija}

In a series of survival strategies, plants have the ability to produce more than 200,000 highly variable and specialized chemical compounds, so-called secondary metabolites, which have no apparent role in the normal functioning of cells. However, these secondary metabolites have significant economic and medical value and there is great interest in their isolation and biological assessment (FABRICANT and FARNSWORTH, 2001; DINDA et al., 2011; LATTANZIO, 2013; WATSON, 2014).

\section{Content of total phenolic compounds analyzed - Sadržaj ukupnih analiziranih fenolnih jedinjenja}

Pharmacological characteristics of plants greatly determine their phenolic composition, which is highly dependent on genotype, phenophase and ecological conditions in which the individual lives. Most plants mainly produce relatively small concentrations of different phenolic compounds that can accumulate under extreme stress conditions (UV radiation, light intensity, drought and mineral deficiency) (DIXON and PAIVA, 1995; ORHAN et al., 2007; WATSON, 2014). However, the composition and activity of plant extracts depends on the plant species, the group of the synthesized compounds and their combinations and the method and type of solvent used (ZHENG and WANG, 2001; OREOPOULOU, 2003). Thus, using the FolinCiocalteu method can not obtain complete quantitative and qualitative representation of total phenolic compounds in plant extracts (KÄHKÖNEN et al., 1999; SINGELTON et al., 1999; ZHENG and WANG, 2001; CAl et al., 2004; SPIRIDON et al., 2011; CIMMINO et al., 2013). JURIKOVA et al. (2012 and literature cited therein) state that the polyphenolic composition of six investigated Lonicera (Caprifoliaceae) species depends significantly on the species, but also on the geographic origin, ie. the ecological conditions in which the individuals lived. Although the berries of the 
investigated Lonicera species were relatively rich in polyphenolic compounds, there was no regularity in their relationships, even within the same species.

Except of Symphoricarpos albus, all other species of genus have, to date, been underestimated with the phytochemical point of view. In various parts of $S$. albus is determined the presence of organic acids, phenolic acids, oxidative phenols, hydroxycinnamic acids, flavonoids, coumarins, tannins, iridoids, saponins, sterols, triterpenes, carbohydrates, pectins and alkaloids (WILLUHN et al., 1983; HALLARD et al., 1998; SZAUFER-HAJDRYCH and ZGÓRKA, 2003 and literature cited therein; KIM et al., 2004; SZAUFER-HAJDRYCH and GOŚLIŃSKA, 2004; MALYI and KHVOROST, 2013). MALYI and KHVOROST (2013) state that organic acids are the most common in leaves, oxidative phenols in shots and leaves, and flavonoids in leaves, while SZAUFER-HAJDRICH and GOŚLIŃSKA (2004) state that the flowers and fruits of $S$. albus have the highest concentration of phenolic acids.

It is known that berries, as well as many other fruits, have a wide variety of phenolic compounds in various conjugate forms and have high antioxidative activity (JURIKOVA et al., 2012). In $S$. albus berries is measured relatively large water content (82-87\%), and the presence of phenolic acids, carbohydrates and iridoides was found (MAKAREVICH et al., 2009 and literature cited therein). MAKAREVICH et al. (2009) isolated 12 compounds in the butanolic extract of dried berries, including secologanin, loganin, the aglycon of loganin and glucologanin. HALLARD et al. (1998) determined in $S$. albus var. laevigatus significantly lower amounts of secologanin than in the leaves of other species of Caprifoliaceae, while KIM et al. (2004) achieved the highest yield of secologanin in $S$. albus berries by ultrasonication with methanol. According to available literature, the contents of phenolic acids, carbohydrates, iridoids, with special emphasis on monoterpene glycoside are investigated in the $S$. albus berries (HALLARD et al., 1998; KIM et al., 2004; SZAUFER-HAJDRYCH and GOŚLIŃSKA, 2004; MAKAREVICH et al., 2009), so the data obtained in this study are the first for this species. Obtained results in this study showed that $S$. albus berries had the lowest values of total phenols, flavonoids and flavanols (Table 1), which could, to some extent, be expected in terms of their white color (GLENNIE, 1969).

According to our knowledge, determination of total phenolics of $S . \times$ chenaultii and $S$. orbiculatus is done for the first time in this study. It was noted that methanol extracts of berries of analyzed Symphoricarpos taxa were relatively poor in total flavanols, phenols and flavonoids, with the exception of $S$. orbiculatus, which had significantly higher concentrations of total flavonoids (Table 1). However, statistical analysis has shown that all three Symphoricarpos taxa differ significantly in polyphenolic composition, which could also be expected on the basis of different color intensity of their white and purplered berries. Therefore, $S . \times$ chenaultii and $S$. orbiculatus can represent a significant source of bioactive organic compounds.

SMITH, (1977) showed that $S$. orbiculatus extracts have a negative allelopathic effect both on seed germination of some grasses, and on abnormal behavior of seedlings, since the shoot first appears and then the radical. Therefore, it is necessary to continue with more detailed research and identification of active 
compounds of these taxa with regard to its use in folk medicine and cattle treatments (NICKELL, 1959; SZAUFER-HAJDRYCH and ZGÓRKA, 2003; LANS et al., 2007).

\section{Antioxidative activity of analyzed Symphoricarpos taxa - Antioksidativna aktivnost istraživanih svojti Symphoricarpos}

Although the antioxidant activity of plant extracts is very different due to their complex chemical composition, it is noted that it is, most often, significantly correlated with the presence and concentration of phenols and flavonoids (SHAHIDI et al., 1992; KÄHKÖNEN et al., 1999; PAGANGA et al., 1999; ROBARDS et al., 1999; SANCHEZ-MORENO et al., 1999; ZHENG and WANG, 2001; CAl et al., 2004; SPIRIDON et al., 2011). Namely, phenolic compounds contribute to higher quality and nutritional value of plants in terms of color, taste and flavor changes, forming and strengthening of antioxidant defense.

Thus phenolic compounds, especially flavonoids, serve as defense mechanisms against reactive oxygen species (ROS), then in the process of survival and prevention of molecular damages, as well as damages induced by microorganisms, insects and plant species (JABERIAN et al., 2013; BABA and MALIK, 2015). Therefore, the total phenol concentration can be used as a basis for a relatively fast checking of antioxidant activity (BABA and MALIK, 2015).

However, the relationship between the antioxidant activity of the extract and the content of the total phenolic compounds is still largely unknown, because antioxidant compounds of the nonphenolic structure (eg. ascorbic acid, tocopherol, pigments and some minerals) are often present in the extracts. In fact, the antioxidant activity of plant extracts can not be predicted based on their total phenols content (KÄHKÖNEN et al., 1999; SINGELTON et al., 1999) because it depends on the concentration, structure and interaction (synergism / antagonism) between antioxidants (SANCHEZ-MORENO et al., 1999; SPIRIDON et al., 2011).

According to available data, a relatively high antioxidant activity of methanol extracts of Symphoricarpos occidentalis Hook. seeds is only found (BORCHARDT et al., 2008), so data on the antioxidant activity of the extracts of the investigated snowberries taxa were presented in this study for the first time. Thus, methanol extracts of $S$. albus berries showed statistically significant and relatively low antioxidant activity (Table 2 ) relative to $S$. $\times$ chenaultii and $S$. orbiculatus.

Obviously, phenolic compounds analyzed in this study are not individually responsible for this characteristic but their antioxidant activity is the possible consequence of 1) the chemical structure of the phenolic compounds, 2) the various combinations and concentrations of the phenolic compounds or 3) the presence and activity of another, in this study, unexplored compound(s). Namely, according to SHARIFIFAR et al. (2008), the antioxidant activity of flavonoids, which are most conducive to the antioxidant nature of plant extracts, mainly depends on the structure and substitution pattern of hydroxyl groups. Therefore it would be advisable to deepen the research on the high antioxidative activity of extracts of analyzed Symphoricarpos berries with some other methods and to isolate their constituent active compounds. 


\section{Antibacterial and antifungal activity of analyzed snowberries taxa - Antibakterijska i antifungalna aktivnost istraživanih svojti biseraka}

Plants are intensively explored, primarily based on ethnobotanical data, to confirm their antimicrobial properties and to isolate new compounds with these properties (LIMA-FILHO and CORDEIRO, 2014). Many authors agree that plant antibacterial activity is a consequence of the action of various chemical agents (active antimicrobial compounds) in their extracts, including essential oils, flavonoids, triterpenoids, other phenolic nature compounds and free hydroxyl compounds (MORRIS et al., 1979; CAKIR et al., 2004; SARAVANAKUMAR et al., 2014). In fact, a very large influence on the antibacterial activity of a plant extract has its concentration and type of extractive solvent, with water-methanol extracts showing better antimicrobial activity than water (JABERIAN et al., 2013). In addition, ALO et al. (2012) indicate that the antimicrobial properties of plant extracts are affected by the age of the plant used, freshness of plant material, physical factors (eg. temperature), microbial contamination in the field and manipulation errors. According to JABERIAN et al. (2013 and literature cited therein), there is a correlation between antimicrobial activity and chemical composition of the extract, whereby alkaloid, phenolic and saponine compounds in plants can, in most cases, inhibit growth of microorganisms.

In general, plant polyphenols are considered to have antimicrobial activity as they are capable to reduce growth or propagation of microorganisms (BABA and MALIK, 2015; BORRÁS-LINARES et al., 2015). However, although antimicrobial activity is most likely attributable to the presence of specific phenolic compounds in the extracts and the possible existence of synergistic effects with other nonphenolic compounds, high values of total phenolic compounds are not always correlated with high antimicrobial activity (BORRÁS-LINARES et al., 2015).

According to available data, Symphoricarpos antimicrobial activity was relatively poorly investigated. NICKELL, (1959) states that sap of complete individuals of $S$. albus has antibacterial activity against gram-negative and gram-positive bacteria. Also, the same author states that $S$. racemosus Michx. has antibacterial activity against gram-negative and gram-positive bacteria, but without information on what the solvent, plant part and bacterial strains are used. SZAUFER-HAJDRYCH and GOŚLIŃSKA (2004) demonstrated that there is a positive correlation between the concentration of phenolic acids in water extracts of leaves, flowers and berries of $S$. albus and their antimicrobial activity on a six tested bacteria and fungi, whereby berry extracts had the strongest activity.

In this study, methanol extracts of berries of $S$. albus showed moderate antibacterial activity against five analyzed bacterial strains (Table 2), and of $S$. $\times$ chenaultii only against three strains. Although $S$. orbiculatus had the highest antioxidant activity it did not show any antibacterial activity at all. All three Symphoricarpos taxa did not exhibit antimicrobial properties against $C$. albicans. In comparison to the presented data of SZAUFER-HAJDRYCH and GOŚLIŃSKA (2004), antibacterial activity of berries extract of $S$. albus against $S$. aureus and $P$. aeruginosa 
is confirmed in this study, but not its antifungal activity against $C$. albicans. Possible reasons for this are most probably the collection of plant material in different phenophase, different ecological conditions in which analyzed individuals lived, applications of different concentrations of methanol extracts and possible synergistic / antagonistic effect of the present compounds in the extracts. Therefore, it is necessary to isolate active compounds and evaluate their antimicrobial activity, individually or in a variety of combinations, in the future.

\section{CONCLUSIONS - Zaključci}

The results obtained in this study show that the investigated species Symphoricarpos albus, $S$. $\times$ chenaultii and $S$. orbiculatus represent a potential source of bioactive compounds that are still not sufficiently explored. The methanol extracts of berries of Symphoricarpos taxa analyzed are relatively poor in total phenols, flavonoids and flavanols, with the exception of $S$. orbiculatus. The methanol extracts of berries of Symphoricarpos orbiculatus, with the highest mean values of total phenols, flavonoids and flavanols, had relatively high antioxidant activity, which is why detailed analysis into the dependence of antioxidant activity on other present bioactive compounds is necessary. The methanol extracts of $S$. albus had moderate antibacterial activity against five analyzed bacterial strains (Bacillus vulgatus, Enterococcus faecalis, Pseudomonas aeruginosa, Salmonella abony and Staphylococcus aureus) and extract of $S . \times$ chenaultii had only against three strains (B. vulgatus, $P$. aeruginosa and $S$ aureus). Although $S$. orbiculatus had the highest antioxidant activity it did not show any antibacterial activity at all. No antifungal activity of methanol extracts of the investigated Symphoricarpos taxa versus $C$. albicans was demonstrated in this study. 


\section{REFERENCES - Literatura}

ALO MN, ANYIM C, IGWE JC, ELOM M, UCHENNA DS. (2012): Antibacterial activity of water, ethanol and methanol extracts of Ocimum gratissimum, Vernonia amygdalina and Aframomum melegueta. Pelagia Research Library. Advances in Applied Science Research 3(2): 844-848.

BABA SA, MALIK SA. (2015): Determination of total phenolic and flavonoid content, antimicrobial and antioxidant activity of a root extract of Arisaema jacquemontii Blume. Journal of Taibah University for Science 9: 449-454.

BAUER AW, KIRBY WMM, SHERRIS JC, TURCK M. (1966): Antibiotic susceptibility testing by a standardized single disk method. American Journal of Clinical Pathology 36: 493-496.

BORCHARDT JR, WYSE DL, SHEAFFER CC, KAUPPI KL, FULCHER RG, EHLKE NJ, BIESBOER DD, BEY RF. (2008): Antioxidant and antimicrobial activity of seed from plants of the Mississippi river basin. Journal of Medicinal Plants Research 2(4): 081-093.

BORRÁS-LINARES I, FERNÁNDEZ-ARROYO S, ARRÁEZ-ROMAN D, PALMEROSSUÁREZ PA, DEL VAL-DÍAZ R, ANDRADE-GONZÁLES I, FERNÁNDEZGUTIÉRREZ A, GÓMEZ-LEYVA JF, SEGURA-CARRETERO A. (2015): Characterization of phenolic compounds, anthocyanidin, antioxidant and antimicrobial activity of 25 varieties of Mexican Roselle (Hibiscus sabdariffa). Industrial Crops and Products 69: 385-394.

CAI Y, LUO Q, SUN M, CORKE H. (2004): Antioxidant activity and phenolic compounds of 112 traditional Chinese medicinal plants associated with anticancer. Life Sciences 74: 2157-2184.

CAKIR T, KIRDAR B, ULGEN KO. (2004): Metabolic pathway analysis of yeast strengthens the bridge between transcriptomics and metabolic networks. Biotechnology and Bioengineering 86: 251-260.

CIMMINO A, ANDOLFI A, ABOUZEID M, EVIDENTE A. (2013): Polyphenols as fungal phytotoxins, seed germination stimulants and phytoalexins. Phytochemistry Reviews 12(4): 653-672.

CROZIER A, CLIFFORD MN, ASHIHARA H. (2006): Plant secondary metabolitesOccurrence, structureand role in the human diet. Blackwell Publishing Ltd. Oxford, UK.

DINDA B, DEBNATH S, BANIK R. (2011): Naturally occurring iridoids and secoiridoids. An updated review, part 4. Chemical and Pharmaceutical Bulletin 59(7): 803-833.

DIXON RA, PAIVA NL. (1995): Stress-induced phenylpropanoid metabolism. Plant Cell 7: 1085-1097. 
EVERETT TH. (1982): The New York Botanical Garden Illustrated Encyclopedia of Horticulture. Taylor \& Francis, New York, USA.

FABRICANT DS, FARNSWORTH NR. (2001): The value of plants used in traditional medicine for drug discovery. Environmental Health Perspectives 109: 69-75.

GADZOVSKA S, MAURY S, DELAUNAY A, SPASENOSKI M, JOSEPH C, HAGĖGE D. (2007): Jasmonic acid elicitation of Hypericum perforatum L. cell suspensions and effects on the production of phenylpropanoids and naphtodianthrones. Plant Cell Tissue Organ Culture 89: 1-13.

GLENNIE CW. (1969): A comparative phytochemical study of Caprifoliaceae. PhD Thesis, Department of Botany, University of British Columbia, Vancouver, Canada.

HALLARD D, VAN DER HEIJDEN R, CONTIN A, JIMÉNÉZ EMT, SNOEIJER W, VERPOORTE R, JENSEN SR, CARDOSO MIL, PASQUALI G, MEMELINK J, HOGE JHC. (1998): An assay for secologanin in plant tissues based on enzymatic conversion into strictosidine. Phytochemical analysis 9: 162-167.

HESSAYON DG. (1994): The Flowering Shrub Expert. Transworld Publishers, London, UK.

JABERIAN H, PIRI K, NAZARI J. (2013): Phytochemical composition and in vitro antimicrobial and antioxidant activities of some medicinal plants. Food Chemistry 136: 237-244.

JACOBS B, LENS F, SMETS E. (2009): Evolution of fruit and seed characters in the Diervilla and Lonicera clades (Caprifoliaceae, Dipsacales). Annals of Botany 104: 253-276.

JONES GN. (1940): A monograph of the genus Symphoricarpos. Journal of the Arnold Arboretum 21(2): 201-252.

JURIKOVA T, ROP O, MLCEK J, SOCHOR J, BALLA S, SZEKERES L, HEGEDUSOVA A, HUBALEK J, ADAM V, KIZEK R. (2012): Phenolic profile of edible honeysuckle berries(Genus Lonicera) and their biological effects. Molecules 17: 61-79.

KÄHKÖNEN MP, HOPIA AI, VUORELA HJ, RAUHA JP, PIHLAJA K, KUJALA TS, HEINONEN M. (1999): Antioxidant activity of plant extracts containing phenolic compounds. Journal of Agriculture and Food Chemistry 47: 3954-3962.

KIM HK, CHOI YH, TEUS LUIJENDIJK JC, VERA ROCHA RA, VERPOORTE R. (2004): Comparison of extraction methods for secologanin and the quantitative analysis of secologanin from Symphoricarpos albus using 1H-NMR. Phytochemical Analysis 15: 257-261.

KOVALENKO SM, GUBIN UI, GUSAROVA TD. (2007): Isolation of the iridoids Symphoricarpos albus. Fitoterapija 2: 65-68. 
LANS C, TURNER N, KHAN T, BRAUER G. (2007): Ethnoveterinary medicines used to treat endoparasites and stomach problems in pigs and pets in British Columbia, Canada. Veterinary Parasitology 148: 325-340.

LATTANZIO V. (2013): Natural Products. U: Ramawat KG, Mérillon JM. (Eds.), Phenolic compounds: Introduction. Springer-Verlag Berlin Heidelberg, Germany. pp. 1543-1580.

LIMA-FILHO JV, CORDEIRO RA. (2014): In vitro and in vivo antibacterial and antifungal screening of natural plant products: prospective standardization of basic methods. U: Albuquerque UP, Cruz da Cunha LVF, Lucena RFP, et al. (Eds.), Methods and Techniques in Ethnobiology and Ethnoecology, Springer Protocols Handbooks. pp. 275-291.

MAKAREVICH IF, KOVALENKO SN, GUSAROVA TD, GUBIN YU I. (2009): Iridoids from Symphoricarpos albus. Chemistry of Natural Compounds 45(1): 40-44.

MALYI VV, KHVOROST OP. (2013): Quantitative content of bas major groups in raw materials of Symphoricarpos albus (L.) Blake and Symphoricarpos occidentalis Hook. Український медичний альманах 16(1): 83-84.

MEDA A, LAMIEN CE, ROMITO M, MILLOGO J, NACOULMA OG. (2005): Determination of the total phenolic, flavonoid and proline contents in Burkina Fasan Honey, as well as their radical scavenging activity. Food Chemistry 91(3): 571-577.

MOERMAN DE. (1998): Native American Ethnobotany. Timber Press, Portland, USA.

MORRIS JA, KHETTRY A, SEITZ EW. (1979): Antimicrobial activity of aroma chemical and essential oils. Journal of the American Oil Chemists' Society 56: 595-603.

NICKELL LG. (1959): Antimicrobial activity of vascular plants. Economic Botany 13(4): 281-318.

ORDOÑEZ A, GOMEZ J, VATTUONE M, ISLA M. (2006): Antioxidant activities of Sechium edule (Jacq.) Swart extracts. Food Chemistry 97: 452-458.

OREOPOULOU V. (2003): Extraction of natural antioxidants. U: Tzia C, Liadakis G. (Eds.), Extraction optimization in food engineering, Marcel Dekker, New York, USA.

ORHAN DD, HARTEVIOGLU A, KÜPELI E, YESILADA E. (2007): In vivo antiinflammatory and antinociceptive activity of the crude extract and fractions from Rosa canina L. fruits. Journal of Ethnopharmacology 112: 394-400.

PAGANGA G, MILLER N, RICE-EVANS CA. (1999): The polyphenolic content of fruit and vegetables and their antioxidant activities. What does a serving constitute? Free Radical Research 30: 153-162. 
ROBARDS K, PRENZLER PD, TUCKER G, SWATSITANG P, GLOVER W. (1999): Phenolic compounds and their role in oxidative processes in fruits. Food Chemistry 66: 401-436.

SANCHEZ-MORENO C, LARRAURI JA, SAURA-CALIXTO F. (1999): Free radical scavenging capacity and inhibition of lipid oxidation of wines, grape juices and related polyphenolic constituents. Food Research International 32: 407-412.

SARAVANAKUMAR G, YOU DG, SON S, HAN HS, HEO R, KIM K, KWON IC, LEE JY, PARK JH. (2014): Dextran sulfate-coated superparamagnetic iron oxide nanoparticles as a contrast agent for atherosclerosis imaging. Carbohydrate Polymers 101: 1225-1233.

SEIGLER DS. (1998): Plant Secondary Metabolism. Kluwer Academic Publisher, London, UK. pp. 592.

SHAHIDI F, JANITHA PK, WANASUNDARA PD. (1992): Phenolic antioxidants. Critical Reviews in Food Science and Nutrition 32(1): 67-103.

SHARIFIFAR F, NUDEH-DEHGHN G, MIRTAJALDINI M. (2008): Major flavonoids with antioxidant activity from Teucrium polium L. Food Chemistry 112: 885-888.

SINGLETON VR, ORTHOFER R, LAMUELA-RAVENTOS RM. (1999): Analysis of total phenols and other oxidation substrates and antioxidants by means of FolinCiocalteu reagent. Methods in Enzymology 299: 152-178.

SMITH L. (1977): The allelopathic potential of Symphoricarpos orbiculatus in the Kansas tall grass prairie. Master thesis, Emporia State University, Division of Biological Sciences, Kansas, USA.

SPIRIDON I, BODIRLAU R, TEACA C-A. (2011): Total phenolic content and antioxidant activity of plants used in traditional Romanian herbal medicine. Central European Journal of Biology 6(3): 388-396.

SZAUFER-HAJDRYCH M, GOŚLIŃSKA O. (2004): The quantitative determination of phenolic acids and antimicrobial activity of Symphoricarpus albus (L.) Blake. Acta Poloniae Pharmaceutica 61(1): 69-74.

SZAUFER-HAJDRYCH M, ZGÓRKA G. (2003): Phenolic acids from Symphoricarpos albus (L.) Blake (Caprifoliaceae). Acta Poloniae Pharmaceutica-Drug Research 61(1): 91-95.

VERMERRIS W, NICHOLSON R. (2008): Phenolic compound biochemistry. Springer Science+Business Media B.V.

VUKIĆEVIĆ E. (1996): Dekorativna dendrologija. Šumarski fakultet, Beograd, Srbija.

WATSON R. (2014): Polyphenols in plants: Isolation, purification and extract preparation. Elsevier Inc., London, UK.

WILLUHN G,MERFORT I, MATTHEISEN UM. (1983): The occurrence of lanosterol and 24-methylenelanost-8-en-3/3-ol in leaves of Symphoricarpus albus. Phytochemistry 22(1): 137-141. 
Total phenolics, antioxidative and antimicrobial activity of methanol extracts of berries of

Symphoricarpos albus (L.) S.f.Blake, S. × chenaultii Rehder and S. orbiculatus Moench

WOLFE K, WU X, LIU HR. (2003): Antioxidant activity of apple peels. Journal of Agricultural and Food Chemistry 51: 609-614.

ZHENG W, WANG SY. (2001): Antioxidant activity and phenolic compounds in selected herbs. Journal of Agriculture and Food Chemistry 49: 5165-5170.

\section{SAŽETAK}

Dobiveni rezultati u ovoj studiji pokazuju da istraživane svojte Symphoricarpos albus, $S$. × chenaultii i $S$. orbiculatus predstavljaju potencijalni izvor bioaktivnih jedinjenja koja još uvijek nisu dovoljno istražena. Metanolni ekstrakti bobica analiziranih svojti Symphoricarpos su relativno siromašni ukupnim fenolima flavonoidima i flavanolima, sa izuzetkom $S$. orbiculatus. Metanolni ekstrakti bobica $S$. orbiculatus sa najvišom srednjom vrijednošću ukupnih fenola, flavonoida i flavanola imaju relativno visoku antioksidativnu aktivnost, pa su neophodna detaljna istraživanja zavisnosti antioksidativne aktivnosti od drugih bioaktivnih jedinjenja. Metanolni ekstrakti plodova $S$. albus imaju umjerenu antibakterijsku aktivnost protiv pet analiziranih bakterijskih sojeva (Bacillus vulgatus, Enterococcus faecalis, Pseudomonas aeruginosa, Salmonella abony i Staphylococcus aureus), $S . \times$ chenaultii samo protiv tri soja (B. vulgatus, $P$. aeruginosa i $S$. aureus). Iako je $S$. orbiculatus imao najveću antioksidativnu aktivnost, on nije pokazao nikakvu antimikrobnu aktivnost. Ovim istraživanjem nije dokazana antifungalna aktivnost metanolnih ekstrakata plodova istraživanih svojti Symphoricarpos protiv C. albicans.

Corresponding author: Fatima Pustahija; Faculty of Forestry University of Sarajevo; Zagrebačka 20, 71000 Sarajevo, Bosnia and Herzegovina; e-mail address: f.pustahija@sfsa.unsa.ba 